\title{
Differential expression of peroxisome proliferator-activated receptor $\gamma$, fatty acid synthase, and hormone-sensitive lipase in fat-tailed and thin-tailed sheep breeds
}

\author{
X.C. Xu, B.B. Li, X. Wei, Y.X. Yang, X.L. Wang and Y.L. Chen \\ College of Animal Science and Technology, Northwest A\&F University, \\ Yangling, China \\ Corresponding author: Y.L. Chen \\ E-mail: xiaochunxuspring@163.com
}

Genet. Mol. Res. 14 (4): 15624-15633 (2015)

Received July 27, 2015

Accepted October 14, 2015

Published December 1, 2015

DOI http://dx.doi.org/10.4238/2015.December.1.14

\begin{abstract}
Tail fat content affects meat quality, and it varies in different sheep breeds. Theoretically, lipid metabolism contributes to variation in tail fat content. Tail length, tail width, and tail girth were measured in live Tong sheep (with both short fat tail and long fat tail), Shaanbei fine wool sheep (long thin tail), Tan sheep (short fat tail), Kazakh sheep (hip fat tail), and Tibetan sheep (short thin tail). The expression levels of genes related to tail adipose tissue lipid metabolism were investigated, which included lipogenetic genes (PPAR $\gamma$ and FAS) and lipolytic gene $(H S L)$. Differences were observed $(\mathrm{P}<0.05)$ in PPAR $\gamma$ mRNA expression levels in the different breeds; FAS mRNA expression levels did not differ $(\mathrm{P}>0.05)$ in Tong sheep with short fat tail, Tong sheep with long fat tail, Shaanbei fine wool sheep, and Tibetan sheep; HSL mRNA expression levels were not different ( $\mathrm{P}>$ 0.05 ) in Tong sheep. PPAR $\gamma$ and HSL protein expression levels differed $(\mathrm{P}<0.05)$ between the different breeds; FAS protein expression levels were different $(\mathrm{P}<0.05)$ in Tong sheep with long fat tails, Tan sheep,
\end{abstract}


Kazakh sheep, and Tibetan sheep, but did not differ $(\mathrm{P}>0.05)$ in Tong sheep with short fat tails and Shaanbei fine wool sheep. These results provide useful information to further understand the function of $P P A R \gamma$, $F A S$, and HSL in sheep tail lipid metabolism, which should be applicable to studies on the regulation of fat deposition and improvement of meat quality.

Key words: PPAR $\gamma$; FAS; HSL; mRNA and protein expression; Sheep; Different tail type

\section{INTRODUCTION}

Multiple livestock species exist in China, including 79 reported sheep breeds. From an ecological basis, they have a variety of advantages such as powerful endurance, rough feeding resistance, and strong disease resistance. Sheep can be divided into several classes, based on the length and form of the tail: short fat tail, long fat tail, short thin tail, long thin tail, and hip fat tail (Zhang et al., 2010). Tong sheep (short fat tail and long fat tail), Shaanbei fine wool sheep (long thin tail), Tan sheep (long fat tail), Kazakh sheep (hip fat tail), and Tibetan sheep (short thin tail) are excellent indigenous sheep breeds in China (Hou, 2009).

Tail fat metabolism is an important surrogate of energy metabolism. It is therefore important to study the expression signature of candidate genes during the metabolism of sheep tail fat. It is crucial to determine the underlying mechanisms of fatty deposition and energy metabolism. Peroxisome proliferator-activated receptor gamma $(P P A R \gamma)$ is the master regulator of adipogenesis, and has been indicated as a critical switch in the commitment of progenitor cells to either the adipogenic or osteogenic pathways (Rosen and Spiegelman, 2001; Nuttall and Gimble, 2004; Muruganandan et al., 2009). Fatty acid synthase (FAS) plays an important role in de novo lipogenesis in mammals, and is a key enzyme in the conversion of acetyl-CoA and malonyl-CoA to triglycerol (TG), while other enzymes are involved in triacylglycerol synthesis (Semenkovich, 1997; Yan et al., 2002; Smith et al., 2003). Hormone-sensitive lipase (HSL) is the rate-limiting enzyme for the hydrolysis of TG to free fatty acid in fat tissues, and is one of the most important factors for controlling the hydrolysis of adipocyte tissues and fat accumulation in animals (Haemmerle et al., 2003; Kazala et al., 2003).

Tail measurements of sheep were found to be significantly correlated to tail fat, carcass fat, and total body fat. Tail fat can be measured easily on live sheep and can be used as a measure of tail weight in breeding programs; however, few studies have addressed this issue by using sheep of various ages and weights. Tails were measured for length $(9.5$ $\pm 0.7 \mathrm{~cm}$ in Mehraban; $18.4 \pm 0.7 \mathrm{~cm}$ in Ghezel), width ( $9.4 \pm 0.4 \mathrm{~cm}$ in Mehraban; 13.1 $\pm 0.4 \mathrm{~cm}$ in Ghezel), and circumference $(16.1 \pm 1.5 \mathrm{~cm}$ in Mehraban; $33.0 \pm 2.2 \mathrm{~cm}$ in Ghezel) by Zamiri and Izadifard (1997). Therefore, the goal of this study was to compare the levels of PPAR $\gamma, F A S$, and $H S L$ expression in different sheep breeds. However, the precise molecular mechanisms responsible for changes in expression remain unclear. These results are expected to provide important information regarding differential regulatory mechanisms of fat deposition. 


\section{MATERIAL AND METHODS}

\section{Animals and sample collection}

Tail adipose tissues were collected from 9-month-old Tong sheep and Shaanbei fine wool sheep in Shaanxi Province, and from Tan sheep, Kazakh sheep, and Tibetan sheep in Ningxia Hui Autonomous Region. Each group included Tong sheep (short fat tail), Tong sheep (long fat tail), Shaanbei fine wool sheep (long thin tail), Tan sheep (long fat tail), Kazakh sheep (hip fat tail), and Tibetan sheep (short thin tail). Each group had 24 sheep (12 males and 12 females) with similar weights (about $23 \mathrm{~kg}$ ), which were maintained under the same stall-feeding condition. Sheep were completely formula-fed in strict accordance with NRC's formula and experimental standards; the formula was developed specifically to satisfy the nutritional needs of the tested sheep. Adipose tissue was collected surgically from the tails. Samples $3 \mathrm{~cm}^{3}$ in size were collected, rapidly frozen in liquid nitrogen, and stored at $-80^{\circ} \mathrm{C}$ until analysis. All the animal experiments were carried out according to the guidelines for animal experiments at the National Institute of Animal Health.

\section{Tail measurements}

Measurements included length, width, and girth of the tail. Length and girth were measured using an ordinary flexible tape measure. Width was measured with calipers designed for this purpose. All measurements were made while the animal was held in a standing position. The measurements were carried out as follows; length: the distance from the leading edge of the first coccygeal vertebra to the end of the tail; width: the straight-line distance of the widest point of the tail; girth: the perimeter at the widest point of the tail.

\section{RNA extraction}

Total RNA was isolated from the frozen tissues using TRIzol reagent (Takara Biotechnology, Dalian, China) according to the manufacturer protocol as previously described (Hemmrich et al., 2010). RNA was dissolved in $20 \mu \mathrm{L}$ ultrapure water and stored at $-80^{\circ} \mathrm{C}$ for use in reverse transcription polymerase chain reaction (RT-PCR) and real-time quantitativePCR (real time-PCR) after RNA integrity was tested on agarose gel electrophoresis. The RNA concentration of the extracts was determined from the absorbance at $260 \mathrm{~nm}$ with a NanoDrop MN-913 spectrophotometer (MAESTROGEN, Taiwan). All samples had a 260/280 nm absorbance ratio of about 1.8-2.0.

\section{Reverse transcription}

Total RNA was reverse-transcribed in a total volume of $20 \mu \mathrm{L}$ using the PrimeScript RT reagent Kit with gDNA Eraser (Perfect Real Time; Takara Biotechnology) containing gDNA Eraser and PrimeScript RT Enzyme Mix, and RT Primer Mix. The reaction was carried out at $37^{\circ} \mathrm{C}, 5 \mathrm{~s}$ at $85^{\circ} \mathrm{C}$, and a final 10 -min extension at $4^{\circ} \mathrm{C}$. 


\section{RT-PCR}

The transcribed cDNA was amplified with TaqDNA polymerase (Takara Biotechnology) by PCR in a thermocycler using paired sense and antisense primers (Table 1). The primers were designed from GenBank sequences using Primer Premier 5.0. Primers were synthesized by Takara Company (Takara Biotechnology). Optimal PCR conditions consisted of an initial 5 -min denaturation at $94^{\circ} \mathrm{C}, 35$ cycles of $30 \mathrm{~s}$ at $94^{\circ} \mathrm{C}, 30 \mathrm{~s}$ annealing at $58^{\circ} \mathrm{C}$, and $45 \mathrm{~s}$ extension at $72^{\circ} \mathrm{C}$, followed by a final 10 -min extension at $72^{\circ} \mathrm{C}$. The PCR products were analyzed by electrophoresis on $1 \%$ agarose gels.

\begin{tabular}{|c|c|c|c|c|}
\hline Genes & GenBank accession No. & Sequence & Product size (bp) & Annealing temperature $\left({ }^{\circ} \mathrm{C}\right)$ \\
\hline$P P A R \gamma$ & NM001100921.1 & $\begin{array}{l}\text { F: 5'-ACGGGAAAGACGACAGACAAA-3' } \\
\text { R: 5'-AAACTGACACCCCTGGAAGATG-3' }\end{array}$ & 150 & $62^{\circ}$ \\
\hline$F A S$ & NM001012669.1 & $\begin{array}{l}\text { F: 5'-CCCAGCAGCATTATCCAGTGT-3' } \\
\text { R: 5'-ATTCATCCGCCATCCAGTTC-3' }\end{array}$ & 87 & $62^{\circ}$ \\
\hline$H S L$ & NM001128154.1 & $\begin{array}{l}\text { F: 5'-CTTTCGCACCAGCCACAAC-3' } \\
\text { R: 5'-CTCGTCGCCCTCAAAGAAGA-3' }\end{array}$ & 136 & $62^{\circ}$ \\
\hline$\beta$-actin & NM001009784.1 & $\begin{array}{l}\text { F: 5'-TGAACCCCAAAGCCAACC-3' } \\
\text { R: 5'-AGAGGCGTACAGGGACAGCA-3' }\end{array}$ & 107 & $61^{\circ}$ \\
\hline
\end{tabular}

\section{Real-time PCR}

The levels of sheep PPAR $\gamma, F A S$, and HSL mRNA expression were tested by realtime RT-PCR using SYBR Premix Ex Taq (Takara Biotechnology). The expression of $\beta$-actin was chosen as the internal reference. The sequences of the primers used to analyze the gene expression levels are shown in Table 1. Thermal cycling parameters were as follows: an initial denaturation step at $95^{\circ} \mathrm{C}$ for $10 \mathrm{~min}$, followed by 40 PCR cycles (dissociation for $15 \mathrm{~s}$ at $95^{\circ} \mathrm{C}$, annealing for $30 \mathrm{~s}$ at $60^{\circ} \mathrm{C}$, and elongation for $45 \mathrm{~s}$ at $60^{\circ} \mathrm{C}$ ), one melting cycle (consisting of $15 \mathrm{~s}$ at $95^{\circ} \mathrm{C}, 30 \mathrm{~s}$ at $55^{\circ} \mathrm{C}$, and a step cycle up to $72^{\circ} \mathrm{C}$ for $45 \mathrm{~s}$ ), and finally a cooling cycle at $72^{\circ} \mathrm{C}$ for $45 \mathrm{~s}$ ). To determine the specificity of the reactions, the quality of PCR amplicons was monitored using post-PCR melt curve analysis of amplification reactions (iQ5 Optical Systerm software) to obtain relative quantification values. For the treated samples, evaluation of $2^{-\Delta \Delta \mathrm{Ct}}$ indicates the fold-change in gene expression relative to the untreated control (Livak and Schmittgen, 2001).

$$
\Delta \Delta \mathrm{Ct}=\left(\mathrm{Ct}_{\text {Target }}-\mathrm{Ct}_{\text {Actin }}\right) \text { Time }_{\mathrm{x}}-\left(\mathrm{Ct}_{\text {Target }}-\mathrm{Ct}_{\text {Actin }}\right) \text { Time }_{0}
$$

\section{Protein extraction}

Proteins were isolated from about $100 \mathrm{mg}$ frozen tissue using a ProteoJET ${ }^{\mathrm{TM}}$ Mammalian Cell Lysis Reagent (Fermentas). Phenylmethanesulfonyl fluoride was added in the right proportions $(1: 100)$ before using the reagent. The total proteins were measured by MaestroNano micro-spectrophotometer (USA).

\section{Antibody}

Protein concentrations of extracts were analyzed by western blot using commercially 
available antibodies purchased from Bioworld Technology, Inc., for PPAR (MB0080) and FAS (MB22759); from Santa Cruz Biotechnology, Inc., for HSL (sc-25843); and from Beijing Biosynthesis Biotechnology Co., LED for GAPDH (bsm-0978M). The secondary antibodies were provided by CWBIOTECH for PPAR (CW0102), FAS (CW0105), HSL (CW0103), and GAPDH (CW0102).

\section{Western blot}

Protein $(80 \mu \mathrm{g})$ was mixed with $5 \mathrm{X}$ sample buffer $(80 \mu \mathrm{g})$. The mixtures were boiled at $100^{\circ} \mathrm{C}$ for $10 \mathrm{~min}$ and separated by sodium-dodecyl sulfate-polyacrylamide gel electrophoresis (SDS-PAGE). Immediately after the electrophoresis, SDS was displaced from the proteins by immersing the gels in $0.5 \%(\mathrm{v} / \mathrm{v})$ acetic acid containing $0.5 \%(\mathrm{v} / \mathrm{v})$ Nonidet P-40, for $10 \mathrm{~min}$ at room temperature. Proteins on the gel were electrotransferred to an immobile membrane at $30 \mathrm{~V}$ overnight with cooling at $4^{\circ} \mathrm{C}$ (PVDF; Millipore Corp., Bedford, MA, USA) in the presence of transfer buffer. The blots were saturated with 5\% non-fat milk in PBS containing $0.1 \%(\mathrm{v} / \mathrm{v})$ Tween-20 (PBS-T). After three washes with PBS-T, the blots were incubated with primary antibodies according to the directions at $4{ }^{\circ} \mathrm{C}$ stay overnight, washed, and incubated with secondary antibody. All antibodies were diluted in $2 \%(\mathrm{w} / \mathrm{v})$ non-fat milk powder in Trisbuffered saline. The transferred proteins were visualized with an enhanced chemiluminescence detection kit (ECL kit, Perkin Elmer, Waltham, MA, USA) (Freeman et al., 2012). Immunoblots were quantified by densitometric analysis, and the protein values were normalized to the loading control (GAPDH). Densitometric analysis of the images was performed using the ImageJ software (Toronto Western Research Institute University Health Network). Relative quantitative expression level $(\%)=\left(\right.$ mean gray value $\mathrm{Target} /$ mean gray value $\left._{\mathrm{GAPDH}}\right) \times 100$.

\section{Statistical analyses}

The mRNA and protein abundance are reported as relative percentages. Data are reported as means \pm SE. Statistical analyses were performed using the SPSS10.1.0 for Windows Software. The means of 12 male and 12 female sheep in each experimental group were subjected to one-way ANOVA. Differences were considered to be significant at $\mathrm{P}<0.05$.

\section{RESULTS}

\section{Comparison of tail measurements}

Tail measurements were different $(\mathrm{P}<0.05)$ among breeds, but no such differences $(\mathrm{P}>$ 0.05 ) were observed in the tail width of Tong sheep (long fat tail) and Tan sheep. All experimental sheep were fully developed and fat was metabolized normally. Fat measurements included the length, width, and girth of the fat tail. The results indicated that it is feasible to measure the fat length, width, and girth using a ruler designed for this purpose (Figure 1).

\section{Comparison of PPAR $\gamma, F A S$, and $H S L$ mRNA expression}

Detailed analysis of the levels of individual gene expression in different sheep breeds revealed that all selected genes were expressed in the selected breeds. Differences in the 
expression of PPAR $\gamma$ mRNA $(\mathrm{P}<0.05)$ were observed in the different breeds; FAS mRNA expression levels were not different $(\mathrm{P}>0.05)$ in Tong sheep of short fat tail, Tong sheep of long fat tail, Shaanbei fine wool sheep, and Tibetan sheep; HSL mRNA expression levels were not different $(\mathrm{P}>0.05)$ in Tong sheep. The PPAR $\gamma$ and FAS mRNA levels were highest in Kazakh sheep, while they were very low in Shaanbei wool sheep and Tibetan sheep. HSL mRNA was the highest in Tibetan sheep, and it was very low in Tong sheep and Kazakh sheep. The results indicated that the PPAR $\gamma$ and FAS mRNA levels were high in fat tail sheep, while they were low in thin tail sheep; the HSL mRNA levels followed the opposite trend (Figure 2A-C).

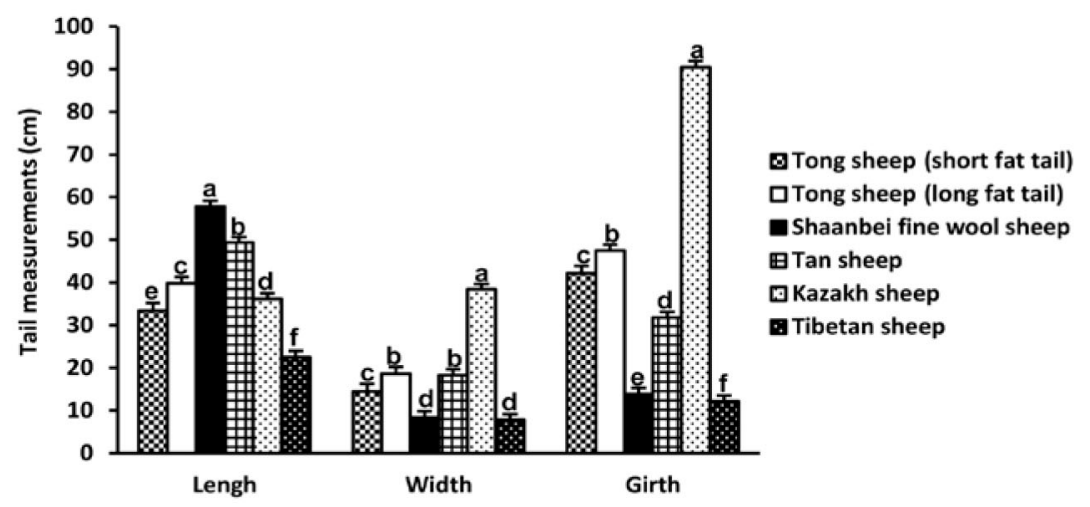

Figure 1. Tail measurements of different breeds: short fat tail Tong sheep, long fat tail Tong sheep, Shaanbei fine wool sheep, Tan sheep, Kazakh sheep, and Tibetan sheep. Data are measurements of tail length, width and girth $(\mathrm{cm})$. Each bar represents means $\pm \mathrm{SE}$. Lowercases $=\mathrm{P}<0.05$.
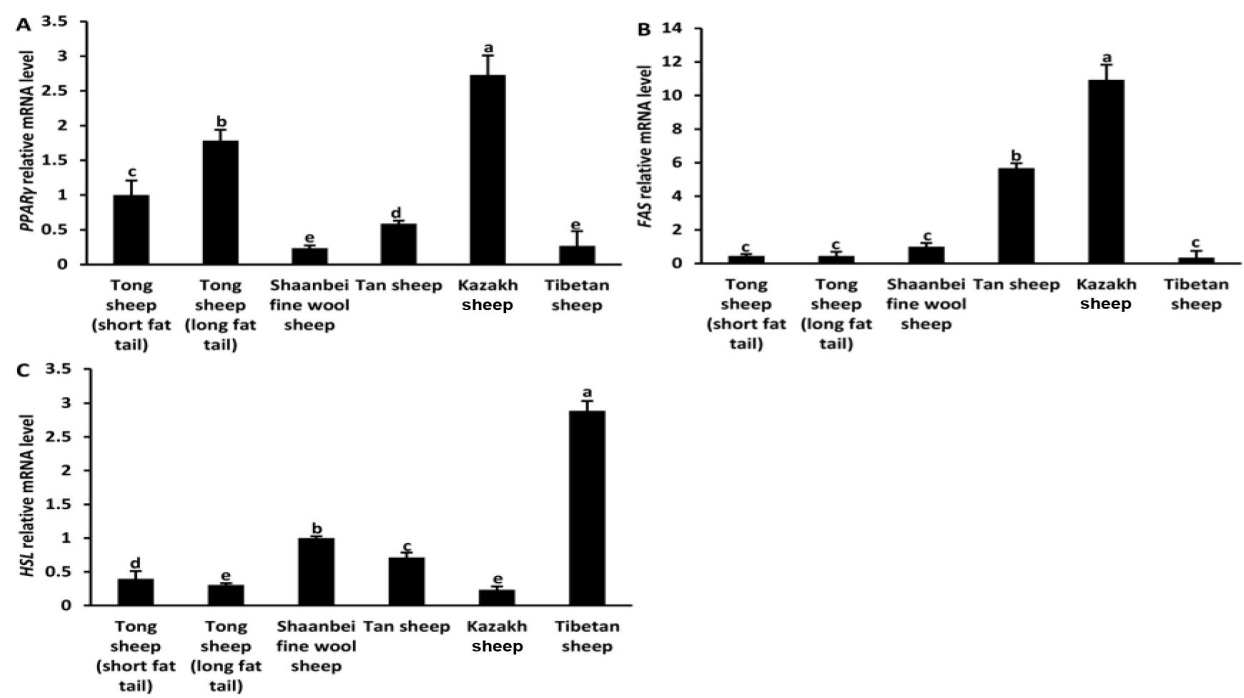

thort fat (long fat sheep

tail) tail)

Figure 2. mRNA levels of PPAR,$F A S$, and HSL genes in different breeds of sheep: short fat tail Tong sheep, long fat tail Tong sheep, Shaanbei fine wool sheep, Tan sheep, Kazakh sheep, and Tibetan sheep. Data are ratios of PPAR $\gamma(\mathbf{A}), F A S(\mathbf{B})$, and HSL (C) mRNA levels normalized to $\beta$-actin (housekeeping gene). Each bar represents means \pm SE. Lowercases $=\mathrm{P}<0.05$. 


\section{Comparison of PPAR $\gamma$, FAS, and HSL protein expression}

The results showed that PPAR $\gamma$ and HSL protein levels were different $(\mathrm{P}<0.05)$ in the different breeds; FAS protein expression levels were different $(\mathrm{P}<0.05)$ in Tong sheep of long fat tail, Tan sheep, Kazakh sheep, and Tibetan sheep, but no such differences $(\mathrm{P}>0.05)$ were observed in Tong sheep of short fat tail and Shaanbei fine wool sheep. The results indicated that PPAR $\gamma$ and FAS protein levels were very high in Kazakh sheep and Tan sheep, while they were low in Shaanbei fine wool sheep and Tibetan sheep. The HSL protein level was very high in Shaanbei fine wool sheep and Tibetan sheep, while it was very low in Tong sheep and Kazakh sheep. The results indicated that PPAR $y$ and FAS protein levels were high in fat tail sheep, while they were low in thin tail sheep; the HSL protein level followed the opposite trend (Figure 3A-C).

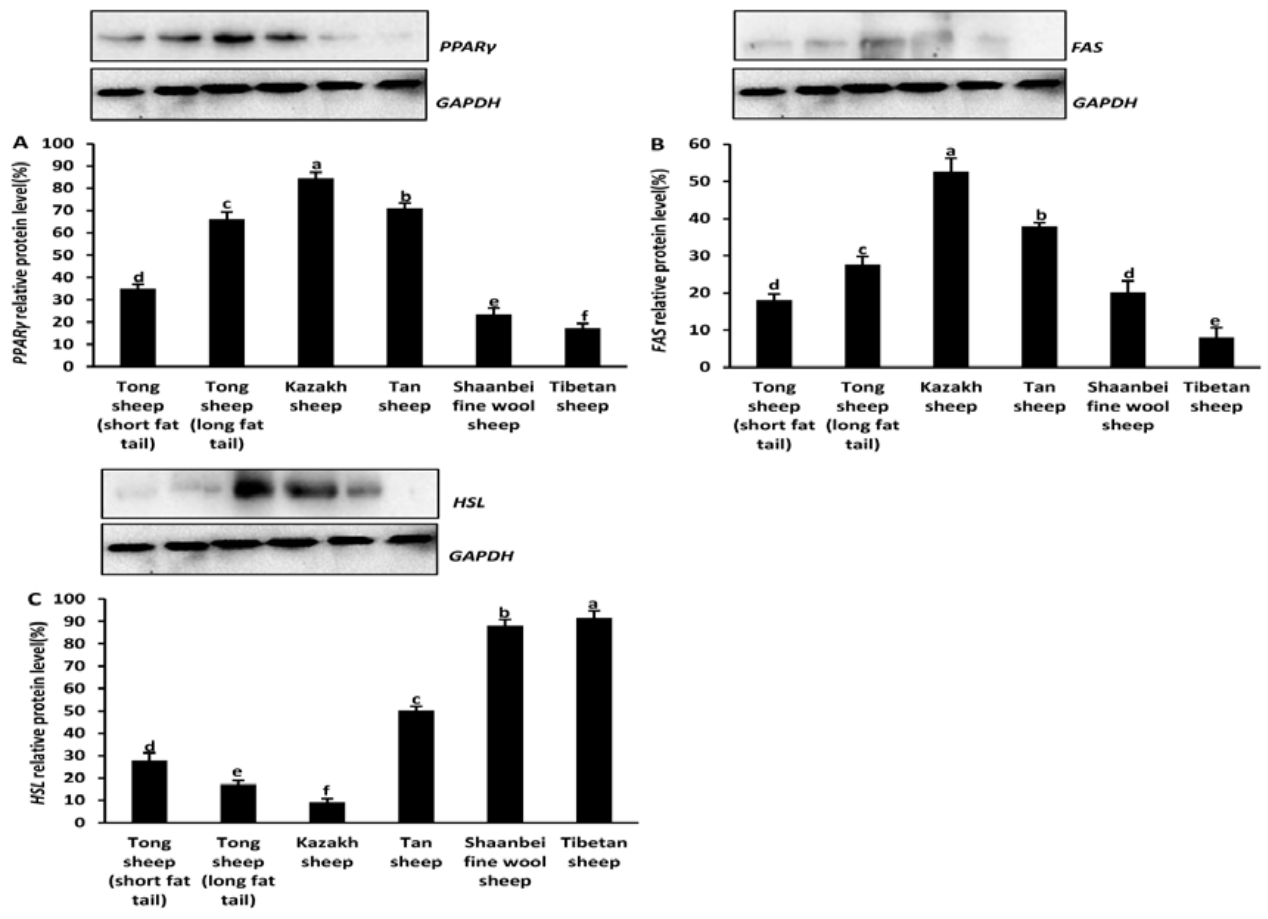

Figure 3. Protein level of PPAR , FAS and HSL genes in different breeds (\%). Protein expression in tail fat of different breeds (from left to right) for PPAR , FAS and GAPDH (short fat tail Tong sheep, long fat tail Tong sheep, Kazakh sheep, Tan sheep, Shaanbei fine wool sheep, and Tibetan sheep) and for HSL (long fat tail Tong sheep, short fat tail Tong sheep, Tibetan sheep, Shaanbei fine wool sheep, Tan sheep and Kazakh Sheep). Data are ratios of PPAR $(\mathbf{A})$, FAS (B) and HSL (C) genes relative protein levels normalized to GAPDH (housekeeping gene) protein levels. Each bar represents means \pm SE. Lowercases $=\mathrm{P}<0.05$.

\section{DISCUSSION}

It is likely that fat-tailed sheep are more tolerant to feed shortage than thin-tailed sheep are. The excess energy is stored as fat when food is plentiful. However, when sheep do 
not have enough sugar (glucose) for energy, the stored fat is broken down (Shelton, 1950). The tolerance of fat-tailed sheep to feed shortage is most likely attributed to the storage of fat in their tails during lush seasons, which can be used during the frequent long periods when plant growth is dormant or in drought years (Sefidbakht and Ghorban, 1972). With the development of science and technology, imprudent sheep husbandry had to gradually adapt to meet production requirements, and it was replaced by formal and standardized production. Previous studies have shown that stall-feeding of sheep was more suitable for production than grazing (Müller et al., 2012). In livestock, excessive fat deposition affects animal health, production efficiency, and marketability of animal products. Reduction of fat deposition in adipose tissues of meat-producing animals is, therefore, highly desirable for both producers and consumers (Jiang et al., 2007). Excessive fat is deposited in sheep tails when stall-feeding is used. We argue that it is meaningful to regulate tail fat deposition. In the present study, sheep were divided into five groups according to their tail type: short fat tail, long fat tail, short thin tail, long thin tail, and hip fat tail. Such categorization is unique in livestock species. To investigate the molecular mechanism of fat deposition, we explored the expression patterns of $P P A R \gamma, F A S$, and $H S L$ in five typical indigenous sheep varieties.

Tan sheep, Tong sheep, and Kazakh sheep, which are fat tail sheep from China, are characterized by their meat quality. These breeds are especially noted for their high-quality meat and high intramuscular fat content; however, a lot of fat is deposited in the tail. By contrast, Shaanbei fine wool sheep and Tibetan sheep are thin tail sheep noted for their lean tails. Previous studies have shown obvious differences in the rates of adipose tissue deposition between lean and fatty pig breeds (Li et al., 2008). An additional study, utilizing a greater number of lambs and evaluating enzymatic activities at different growth stages, has investigated whether the activity of these enzymes is a reliable indicator of carcass fatness in sheep as it is in pigs (Panopoulou et al., 1989). Thus, it was not surprising that, despite the differences between the two breeds in the overall tendency to fatness, they deposited large and similar amounts of fat in the tail and rump, which are the deposits most responsive to nutritional changes in these breeds (Negussie et al., 2003). This suggests that tail fat deposition is controlled by genetic factors, while environmental and nutritional factors had little effect.

Most tail measurements in live animals show a favorable genetic correlation between the weight of tail and rump fat. However, the tail volume of live animals was more closely associated with the combined weight of the dissected tail and rump fat in sheep (Safdarian et al., 2008). The tail volume of live animals was also highly heritable. In this study, tail length was the longest in Shaanbei fine wool sheep, and was the shortest in Tibetan sheep of the same age; tail width and girth were the highest in Kazakh sheep and the lowest in Tibetan sheep of the same age. This shows that the highest amount of fat is deposited in Kazakh sheep tails, the second highest in Tong sheep and Tan sheep, and the lowest in Shaanbei fine wool sheep and Tibetan sheep. Tail volume is a promising candidate for inclusion in selection indices aimed at genetic improvement of body energy reserves, and thus, adaptation to variability in the quantity and quality of feed supply in the sheep and, possibly, other tropical fat-tailed sheep breeds. However, it is recommended that genetic associations of this tail measurement with other components of production be studied using larger data sets.

$P P A R \gamma$ and $F A S$ promote fat synthesis, while $H S L$ promotes fat degradation (Adams et al., 1997; Teruel et al., 2005; Sankaranarayanapillai et al., 2013). Previous studies have shown obvious differences in the rate of adipose tissue deposition between lean and fatty pig breeds (Li et al., 2008). Thus, even with positive genetic correlations between body weight and fat- 
tail measurements, it is possible to increase the body weight and reduce fat-tail size by multitrait selection, because genetic correlations are not perfect (Vatankhah and Talebi, 2008). In this study, the highest mRNA levels of PPAR $\gamma$ and FAS were detected in Kazakh sheep, while the lowest were detected in Tibetan sheep. The mRNA level of $H S L$ followed an opposite trend. PPAR $\gamma$ mRNA levels were higher in Tong sheep than in Tan sheep; FAS and HSL mRNA levels of Tan sheep were higher than those of Tong sheep. The difference in PPAR $\gamma$ and HSL mRNA levels between the two types of Tong sheep was striking. We found no significant difference in the level of $F A S$ mRNA between short fat-tailed sheep and long fat-tail sheep. This may indicate that $P P A R \gamma$ and $F A S$ play a major role in fat synthesis and metabolism. This result was consistent with that reported by Li et al. (2008).

In this study, we determined the levels of PPAR , FAS, and HSL mRNA and protein expression in tails from fat-tailed sheep and thin-tailed sheep. Our data revealed that the levels of PPAR , FAS, and HSL mRNA were similar to those of the corresponding proteins. For each analysis, the correlation between mRNA levels and protein abundance, or the expression of a limited number of highly abundant proteins is discussed. Nicole et al. (2001) demonstrated that levels of brain-derived neurotrophic factor (BDNF) protein closely followed the pattern of mRNA expression in response to estrogen and exercise. BDNF protein levels across all conditions correlated most closely with mRNA changes in the dentate gyrus. Hoggard et al. (1997) reported that high mRNA and protein levels of leptin and its receptor were expressed in the placenta. Future large-scale analyses that aim to correlate mRNA and protein expression levels might determine similar complex patterns of transcriptional and posttranscriptional control, as long as data clustering is based on the fact that proteins function in pathways and complexes.

In conclusion, we have demonstrated that there are significant differences in the expression of PPAR , FAS, and HSL genes between fat-tailed and thin-tailed sheep. Tail measurements were consistent with PPAR , FAS, and HSL gene expression. These results provide insight into the roles played by these genes in lipid metabolism in sheep, and may have practical applications for the manipulation of lipid metabolism and improvement of meat quality in sheep.

\section{Conflicts of interest}

The authors declare no conflict of interest.

\section{ACKNOWLEDGMENTS}

Research supported by the National Special Research Fund for Non-Profit Sector (Agriculture) (\#20130305905) and the China Agriculture Research System (\#CARS-40-13). We are grateful to Ningxia Tan Sheep Breeding Centers and Shaanxi Tong Sheep Foundation Seed Farm for their kind help and cooperation during the sample collection.

\section{REFERENCES}

Adams M, Montague CT, Prins JB, Holder JC, et al. (1997). Activators of peroxisome proliferator-activated receptor gamma have depot-specific effects on human preadipocyte differentiation. J. Clin. Invest. 100: 3149-3153.

Berchtold NC, Kesslak JP, Pike CJ, Adlard PA, et al. (2001). Estrogen and exercise interact to regulate brain-derived neurotrophic factor mRNA and protein expression in the hippocampus. Eur. J. Neurosci. 14: 1992-2002. 
Freeman LR, Zhang L, Dasuri K, Fernandez-Kim SO, et al. (2012). Mutant amyloid precursor protein differentially alters adipose biology under obesogenic and non-obesogenic conditions. PLoS One 7: e43193.

Haemmerle G, Zimmermann R and Zechner R (2003). Letting lipids go: hormone-sensitive lipase. Curr. Opin. Lipidol. 14: 289-297.

Hemmrich K, Denecke B, Paul NE, Hoffmeister D, et al. (2010). RNA Isolation from Adipose Tissue: An Optimized Procedure for High RNA Yield and Integrity. Lab. Med. 41: 104-106.

Hoggard N, Hunter L, Duncan JS, Williams LM, et al. (1997). Leptin and leptin receptor mRNA and protein expression in the murine fetus and placenta. Proc. Nat. Acad. Sci. U. S. A. 94: 11073-11078.

Hou WT (2009). Important Genetic Resources of the Native Domestic Animals in Northwestern China. 1st edn. China Agriculture Press, Beijing.

Jiang JP, Zhou J, Chen J, Wei XH, et al. (2007). Effect of chicken egg yolk antibody against adipose tissue plasma membranes on carcass composition and lipogenic hormones and enzymes in pigs. Livestock Sci. 107: 235-243.

Kazala EC, Petrak JL, Lozeman FJ, Mir PS, et al. (2003). Hormone-sensitive lipase activity in relation to fat content of muscle in Wagyu hybrid cattle. Livest. Prod. Sci. 79: 87-96.

Li MZ, Li XW, Zhu L, Teng XK, et al. (2008). Differential expression analysis and regulatory network reconstruction for genes associated with muscle growth and adipose deposition in obese and lean pigs. Prog. Nat. Sci. 18: 387-399.

Livak KJ and Schmittgen TD (2001). Analysis of relative gene expression data using real-time quantitative PCR and the $2^{-\Delta \Delta \mathrm{Ct}}$ method. Methods 25: 402-408.

Müller K, Lin L, Wang C, Glindemann T, et al. (2012). Effect of continuous v. daytime grazing on feed intake and growth of sheep grazing in a semi-arid grassland steppe. Animal 6: 526-534.

Muruganandan S, Roman AA and Sinal CJ (2009). Adipocyte differentiation of bone marrow-derived mesenchymal stem cells: cross talk with the osteoblastogenic program. Cell Mol. Life Sci. 66: 236-253.

Negussie E, Rottmann OJ, Pirchner F and Rege JEO (2003). Patterns of growth and partitioning of fat depots in tropical fat-tailed Menz and Horro sheep breeds. Meat Sci. 64: 491-498.

Nuttall ME and Gimble JM (2004). Controlling the balance between osteoblastogenesis and adipogenesis and the consequent therapeutic implications. Curr. Opin. Pharmacol. 4: 290-294.

Panopoulou E, Deligeorgis SG, Papadimitriou T and Rogdakis E (1989). Carcass composition, size of fat cells and NADPH-generating dehydrogenases activity in adipose tissue of the fat-tailed Chios and the thin-tailed Karagouniko sheep breed. J. Anim. Breed. Genet. 106: 51-58.

Rosen ED and Spiegelman BM (2001). PPAR $\gamma$ : a nuclear regulator of metabolism, differentiation, and cell growth. J. Biol. Chem. 276: 37731-37734.

Safdarian M, Zamiri MJ, Hashemi M and Noorolahi H (2008). Relationships of fat-tail dimensions with fat-tail weight and carcass characteristics at different slaughter weights of Torki-Ghashghaii sheep. Meat Sci. 80: 686-689.

Sankaranarayanapillai M, Zhang N, Baggerly KA and Gelovani JG (2013). Metabolic shifts induced by fatty acid synthase inhibitor orlistat in non-small cell lung carcinoma cells provide novel pharmacodynamic biomarkers for positron emission tomography and magnetic resonance spectroscopy. Mol. Imaging Biol. 15: 136-147.

Sefidbakht N and Ghorban K (1972). Changes arising from docking of fat tailed sheep in feedlot performance. Iran. J. Agric. Res. 1: 72-77.

Semenkovich CF (1997). Regulation of fatty acid synthase (FAS). Prog. Lipid Res. 36: 43-53.

Shelton HM (1950). The Hygienic System in: Fasting and Sun Bathing. 3rd edn. Dr. Shelton's Health School, San Antonio.

Smith S, Witkowski A and Joshi AK (2003). Structural and functional organization of the animal fatty acid synthase. Prog. Lipid Res. 42: 289-317.

Teruel T, Hernandez R, Rial E, Martin-Hidalgo A, et al. (2005). Rosiglitazone up-regulates lipoprotein lipase, hormonesensitive lipase and uncoupling protein-1, and down-regulates insulin-induced fatty acid synthase gene expression in brown adipocytes of Wistar rats. Diabetologia 48: 1180-1188.

Vatankhah M and Talebi MA (2008). Genetic parameters of body weight and fat-tail measurements in lambs. Small Rumin. Res. 75: 1-6.

Yan XC, Wang YZ and Xu ZR (2002). Regulation of fatty acid synthase (FAS) gene expression in animals. Acta Zoonutrimenta Sin. 2: 1-4.

Zamiri MJ and Izadifard J (1997). Relationships of fat-tail weight with fat-tail measurements and carcass characteristics of Mehraban and Ghezel rams. Small Rumin. Res. 26: 261-266.

Zhang YJ (2010). Sheep and Goat Production. 1st edn. China Agricultural University Press, Beijing. 